811.163.41'26

81'272(497.1)

https://doi.org/10.18485/sj.2021.26.1.12

ВЕЉКО Ж. БРБОРИЋ ${ }^{*}$

Оригинални научни рад

Универзитет у Београду

Примљен: 10. 11. 2020.

Филолошки факултет

Прихваћен: 12. 1. 2021.

\title{
ЈЕЗИЧКИ СПОРОВИ ПОСЛЕ НОВОСАДСКОГ КЊИЖЕВНОГ ДОГОВОРА: ОД ДЕКЛАРАЦИЈЕ ДО ПРЕДЛОГА*
}

\begin{abstract}
У прилогу се говори о језичком расколу између Срба и Хрвата који је уследио после Новосадског књижевног договора. Наиме, Новосадски договор имао је намеру да ојача језичко заједништво српскохрватског језика и иницирао је израду заједничког правописа, заједничког речника и заједничке терминологије. Најзначајније институције науке и културе тадашње Републике Хрватске, на челу са Матицом хрватском и Друштвом књижевника Хрватске су 1967. године стале иза Деклараиије о називу и положају хрватског кьижевног језика. На то је из Београда одговорено незваничним документом који је носио радни наслов Предлог за размишљање. Био је то увод у хрватско одступање од Новосадског договора и заједничког језика. Овај прилог покушава осветлити тај период и указати на неке неспорне чињенице и показати да су језичке несугласице биле увод у друштвене несугласице, које ће резултирати нестанком друге Југославије, настанком нових држава и преименовањем заједничког језика у националне језике.
\end{abstract}

Кључне речи: српски језик, језички неспоразуми и сукоби, Новосадски књижевни договор, Декларащија о језику, Предлог за размишљање.

*brboricv@fil.bg.ac.rs

** Рад је резултат истраживања на пројекту Српски језик и његови ресурси: теорија, опис и примена (бр. 178006), који финансира Министарство просвете, науке и технолошког развоја Републике Србије. 


\section{1. УВОД}

У српској лингвистичкој литератури повремено се говорило о језичкој политици у двадесетом веку. Заправо, стицајем различитих околности крајем деветнаестога века, Вуков језички и правописни модел српског језика био је прихваћен у каснијим „истојезичним републикама”, данас самосталним државама. Вуков језички модел био је преузет и прихваћен у Хрватској, Босни и Херцеговини и Црној Гори неколико деценија пре стварања прве Југославије. О томе сведоче бројни документи и релевантна литература и то више није потребно посебно доказивати, али је, очито, потребно понављати. Стварањем прве Југославије (1918) биле су одмах уочљиве и неке језичке нетрпељивости, посебно је било реакција са хрватске стране, понајвише пред Други светски рат, а екстремно су биле испољене током рата. У међуратном периоду није била видљива било каква засебна језичка политика у Босни и Херцеговини и Црној Гори, нити је било оспоравано језичко заједништво. После Другог светског рата било је озбиљних језичких несугласица и међу институцијама и међу језичким стручњацима, прво између Срба и Хрвата, а потом, с неједнаким интензитетом несугласице су кренуле и у Босни и Херцеговини и, на крају, у Црној Гори. Језичко јединство најјаче је оспоравано после Новосадског књижевног договора. ${ }^{1}$ Заправо, језичка политика водила се из различитих институционалних центара и, по нашем мишљењу, озбиљним пројектом из Хрватске припреман је терен за стварање „различитих” језичких стандарда и политичко раздвајање по републичким границама. Матица хрватска је имала веома активну улогу, била је утицајна институција и чини се да је са хрватске стране одиграла кључну улогу у разградњи језичког и политичког заједништва. Наравно, језик и језички стандард су били само добар изговор и згодан повод за оно што ће уследити крајем XX века. Ипак, о неким важним догађајима не знамо довољно, јер су неке чињенице остале помало замагљене. Добрим делом је то избегавано због крхког језичког заједништва и декларативног „братства и јединства", али је било и нашег немара. Јасно је да језичку политику нису водили језички стручњаци, већ су политички центри и партија били њима надређени. Понекад се „бежало” од чињеница, „заборављана” су званична документа, немамо њихов ваљан попис и опис, па се може стећи слика да смо били и неодговорни. Разлози таквих поступака нису сада посебно важни,

${ }^{1}$ Језичко јединство, постигнуто је крајем деветнаестога века, озваничено је стварањем прве Југославије, а оспорено је пред Други светски рат и поново је успостављено после Другог светског рата. Уследио је Новосадски књижевни договор и један Правопис 1960. године. После је са хрватске стране кренуло неповратно „бежање” из језичке и политичке заједнице. „Наиме, Хрвати су још од 1967. године на језичко и политичко јединство гледали са оспоравањима. Први покушај 'бежања' од јединства била је Декларација о хрватском језику, а онда су раних седамдесетих уследиле и уставне одредбе о хрватском језику и засебан Хрватски правопис" (Брборић 2015: 31). 
али је неспорна чињеница да се многи значајни документи налазе у архивама и да нису истражени. Од истине се не бежи, са истином се живи. Због тога сматрамо да је нужно учинити доступним важна језичка документа језичке политике и дати њихове коментаре и објашњења.

\section{2. УВИД У ЛИТЕРАТУРУ}

Идеја о заједничком језику Срба и Хрвата снажно је артикулисана са Илирским покретом и скоро стотину година чекало се на њену реализацију. У литератури се често помиње Бечки кьижевни договор, али вреди поновити да то није био никакав званични договор, да је пре реч о неформалном састанку и да он није покренут из Србије, нити је иза њега стајао Београд. „У Бечу су ce 1850. године представници српске и хрватске интелигенције сусрели на неформалном састанку, касније названим Бечки књижевни договор, и сложили око избора дијалеката за заједнички књижевни језик, као и око јединства правописа" (Милановић 2004: 131). Заправо, овај „договор” само је потврдио Вуков избор јужног (источнохерцеговачког) наречја и Вукову тврдњу да наречја не треба мешати, већ изабрати једно. Будуће „истојезичне републике” су веома благонаклоно гледале на Вуков избор и договор у Бечу, па су га у потоњим деценијама прихватиле, без било каквог утицаја или наметања из Београда или из Србије.

Стварањем прве Југославије декларативно је створен заједнички језик Срба и Хрвата, а званичном називу језика претходило је поменуто прихватање Вуковог језика од стране Хрвата и оно је, у правом смислу, озваничено у последњој деценији деветнаестога века. Илустративан је цитат Милоша Ковачевића: „Прво, да су Хрвати свој данашњи књижевни (стандардни) језик, који они зову 'хрватски' преузели од Срба у 19. веку - недвосмислено показују изјаве и деловања тадашњих најутицајнијих хрватских филолога. Тако сам Људевит Гај, вођа илирског покрета, који је и најзаслужнији за хрватско преузимање српског језика, године 1852. пише у загребачким 'Народним новинама' да су Хрвати 'пригрлили' српски језик, док шест година раније у 'Даници илирској' образлаже да тзв. илирски језик и није ништа друго него српски језик. (...) А зар (...) недвосмислено не говори да је прво нормирање хрватског књижевног језика извршио Томо Маретић 1899. у својој граматици и стилистици, узимајући за корпус искључиво српске народне песме, приче и пословице, као и језик Вука Караџића и Ђуре Даничића" (Ковачевић 2005: 47-48). Ова тврдња повремено је оспоравана са хрватске стране, али поред неспорних чињеница довољна су признања хрватских лингвиста Ивана Броза (1892) и Далибора Брозовића (1985). Овим тврдњама докази нису потребни и цитати познатих хрватских лингвиста у размаку од скоро једног века остају 
трајно сведочанство хрватског избора књижевног (стандардног) језика. 1. „Ја sam izradio pravila u glavnome prema načelima kojih se držao Vuk i Daničić, a samo gdešto odstupio sam od njihova pisanja” (Броз 1892: III). 2. „Brozov pravopis unosi u hrvatsku jezičku praksu fonološka pravopisna načela, otprilike ona ista koja je kod Srba inaugurisao Karadžić još 1818. godine svojim velikim Srpskim rječnikom" (Брозовић 1985: 10). ${ }^{2}$

Истина, после настанка прве Југославије,у почетку, званични назив језика је био српско-хрватско-словеначки, у складу са називом државе.

У књизи Милоша Окуке Српски на кризном путу налазимо осврт на период после Другог светског рата и шире образложење: „U političkom životu Jugoslavije već je odavno nastupio val decentralizacije i obračun sa nosiocima starih ideja i metoda upravljanja. Privredne reforme započete šezdesetih godina nisu davale očekivane rezultate, za što su optuživani unitaristi. Tražili su se izlazi iz krize, tražile su se i nalazile žrtve. Tako je došlo i do dramatičnog pada Rankovićeve frakcije 1966. godine i do otvaranja puta preteranoj federalizaciji zemlje. U takvim prilikama se u martu 1967. godine pojavila i glasovita Deklaracija o nazivu i položaju hrvatskog književnog jezika, iza koje su, arogantno i organizovano, stajale gotovo sve važnije kulturne, književne i naučne ustanove i organizacije Hrvatske" (Окука 2006: 230). У књизи Социолингвистички проблеми међу Јужним Словенима америчког социолингвисте Кенета Нејлора, у раду „Вуков језик и књижевни српскохрватски данас" (Нејлор 1996: 154-165), налазимо занимљиву елаборацију о заједничком књижевном језику Срба и Хрвата од 1818. године. ${ }^{3}$ Укупан, безмало двовековни, развој модерног српскохрватског књижевног језика К. Нејлор види кроз шест фаза. Прва фаза је прихватање Вуковог модела од стране хрватских интелектуалаца, али отпори од стране културне врхушке, и то је период од 1820. до 1850. Друга фаза је прихватање од стране Хрвата и млађе генерације код Срба, и то је период од 1850. до 1875. Следи трећа фаза, прихватање и од стране Срба и од стране Хрвата, и то је у периоду од 1875. до 1920. Четврта фаза прихватање од стране југословенске владе и „stanovništva svih nacionalnosti, sa neznatnim razlikama” од 1920. до 1940. Тада је српскохрватски био „službeni jezik Jugoslavije”. У петој фази уследило је одбацивање од стране Хрвата током Другог светског рата од 1940. до 1945. „uglavnom zbog nacističkog uticaja”. Шеста фаза била је поновно прихватање

\footnotetext{
${ }^{2}$ Коментаришући хрватски избор Павле Ивић је духовито рекао да је Вуков принцип „пиши као што говориш” у Загребу тумачен „пиши као Вук” (Ивић 1998: 12).

${ }^{3}$ Књига Кенета Нејлора објављена је код нас 1996. године, садржи радове изнете на различитим скуповима (од 1973. до 1991. године). Рад из кога је цитат заправо је „нешто измењена верзија текста" који је К. Нејлор изнео 1988. године на Научном састанку слависта у Вукове дане (Реферати и саопштења 17/1), у Београду. Занимало нас је како на све ово гледа неко са стране, из Америке, а Нејлор је био добар познавалац социолингвистичких прилика на нашим просторима.
} 
заједничког језика од стране Срба и Хрвата, као језика који припада и једнима и другима, са посебним значајем Договора из Новог Сада из 1954. године. Ова фаза је трајала од 1946. до 1966. године. „Kad razmotrimo hrvatsku deklaraciju iz 1967. godine, koja proglašava poseban 'hrvatski jezik', onda to možemo uzeti kao početak sedme faze koja predstavlja sadašnju situaciju" (Нејлор 1996: 156). То, по мишљењу К. Нејлора, значи да је одступање Хрвата од заједничког књижевног језика за Србе и Хрвате од стране хрватске интелигенције, заправо био почетак краја заједничког језика и припрема за урушавање заједничке државе. Прво су, смишљено и организовано, отворени разговори о варијантама и будућим „новим” језицима, најпре српском и хрватском, потом бошњачком и црногорском. Дакле, К. Нејлор у двовековном развоју српскохрватског језика истиче хрватску Декларацију из 1967. године као завршну фазу језичког заједништва и најаву језичког раздвајања, а то ће касније резултирати и стварањем националних држава и националних језика.

Закључци договора у Новом Саду сведочили су другачије, они су често цитирани и више су него јасни: „Народни језик Срба, Хрвата и Црногораца један је језик” (...) „У називу језика нужно је увек у службеној употреби истаћи оба његова саставна дела” (...), „Заједнички језик треба да има и заједнички правопис" (Правопис 1960: 7). Дакле, од 1954. до 1967. године можда је било „оговарања”, али није било „оспоравања” тврдње о једном језику. После Деклараиије, то је данас јасно, Хрвати су решили да за њих језичко заједништво не постоји и, уз озбиљне припреме, чекали су крај језичког и политичког „суживота” са Србима.

У често цитираној књизи Српски народ и његов језик, осврћући се на Декларачију, Павле Ивић јасно каже да је она захтевала да се „хрватски” и „српски” прогласе посебним књижевним језицима, али је остао у уверењу да се то неће десити. Наиме, веровао је у дискусију о језику и правопису која је уследила после анкете која је потекла 1953. године у Летопису Матице српске, Новосадски књижевни договор и његове конкретне резултате око израде заједничког правописа и првих томова речника. Ипак, да је Декларачија била крупан догађај, сведоче и ове речи П. Ивића: „Размишљајући над текстом Декларације, не можемо се отети утиску да она садржи нејако образложење за крупне кораке које је предложила" (Ивић 1971: 213).

У књизи О језичком расколу - сочиолингвистички огледи I такође налазимо тврдњу да је Декларащија била политички мотивисана и да је иза тога стајала идеја о подривању заједничке државе: „А онај ко је 1967. године - преко језика и језичке политике - ударио у саме темеље заједничке државе имао је, у ствари, државни врх за собом” (Брборић 2000: 13).

${ }^{4}$ У књизи О језичком расколу - сочиолингвистички огледи I могу се наћи у целини и текст Декларащије и текст Предлога (Брборић 2000: 13-17). Код нас је мало публикација у којима су 
У раду Језичка политика у Босни и Херчеговини после Другог светског рата Срето Танасић објашњава узроке и поводе који су довели до појаве Декларачије. Наравно, објашњава и праве мотиве Декларащије: „У складу са овим ставовима износи се и захтјев да се у савезном уставу измијени члан којим се регулише ова материја, те да се умјесто одредбе о употреби српскохрватског, односно хрватскосрпског језика унесе одредба гдје се посебно наводе хрватски и српски књижевни језик” (Танасић 2012: 186-187). Из овог, прилично обимног, Танасићевог рада сазнајемо доста чињеница које су претходиле Декларащији и Предлогу, као реакцији из Београда на њену појаву. Танасић каже да је Милка Ивић на Петом конгресу југославенских слависта (Сарајево, 1965) прочитала реферат Проблем норме у књижевном језику и да је говорила о стогодишњем развоју Вуковог језика, уз напомену да се разликују две варијанте - источна и западна, да разговори о варијантама не поткопавају језичко јединство и да нису опасни када је посреди језичко заједништво. Лингвисти из Загреба су ово једва дочекали, подржали су тезу о варијантама, али су је брзо ширили на три или четири варијанте, истовремено отварајући тако простор „увођењу” различитих језичких стандарда (Танасић 2012: 171-222).

\section{3. ДВА ДОКУМЕНТА - ДЕКЛАРАЦИЈА И ПРЕДЛОГ}

Два кратка документа била су, бар у формалном смислу, увод у дефинитивно и неповратно језичко размимоилажење Београда и Загреба, односно оспоравање језичког заједништва била је добра припрема за нестајање заједничке државе у последњој деценији двадесетога века. Истина, за неке остаје отворено питање да ли је ово све било добро организовано и политички осмишљено или је посреди коинциденција. Нама се чини, бар из данашње перспективе, да је реч о јасном пројекту, да је језик био у служби политике и да се ништа није десило случајно. О чему се заправо ради?

После неколико неуспелих покушаја оспоравања Новосадског договора из 1954. године са хрватске стране уследио је докуменат назван Декларација о називу и положају хрватског књижевног језика, представљен у пролеће 1967. године, иза ког су стале све значајне институције науке и културе у Хрватској, њих 19 (Прилог 1). Очито је било речи о добро планираној и синхронизованој акцији. ${ }^{5}$

ова два документа коментарисана. По сведочењу Бранислава Брборића, у Србији се тешко могло доћи до текста Предлога све до краја двадесетог века (Брборић 2000: 17). Декларација је имала другу судбину: њене основне идеје прво су ушле као уставни амандмани, а потом су се нашле у тексту Устава Републике Хрватске и, на неки начин, Устава заједничке државе (1974).

${ }_{5}^{5}$ Без писаног трага и материјалних доказа тешко је понекад доказати и реалне претпоставке. Ипак, са дистанце неке ствари постају јасније и претпоставке бивају и очигледније. Да- 
Декларација је била јасан показатељ да хрватске научне и културне институције не желе језичко и политичко јединство и да траже начин како да то реализују. Наводна угроженост и неравноправност били су изговори и оно што је било на Брионском пленуму само их је ојачало у отвореном признању како (не) виде заједничку будућност. ${ }^{6}$

На Деклараиију је из Београда реаговано документом који је назван Предлог за размишљьљь. Мора се јасно рећи да иза Предлога није стала нити једна институција из Србије, формално је то био предлог групе чланова Удружења књижевника Србије и нека врста одговора на Декларащију, али ни Удружење књижевника Србије није гласало о овом тексту и није га усвојило. Ипак, стицајем околности и одлуком политичких моћника, Декларација, иза које су стале све научне и културне институције Хрватске и незваничан докуменат Предлога, иза кога није стала ни једна институција, посматране су у истој равни и политички моћници су их изједначили. ${ }^{7}$ Већ смо рекли да мислимо да је реч о политичкој одлуци на највишем државном (савезном) нивоу. Два документа неједнаке садржине и различитих намера била су изједначена, и то је (п)остала велика заблуда.

У литератури се најчешће Декларација и Предлог држе у истој равни и посматрају се као идентични документи, један хрватски, други српски, подједнако штетни језичком и политичком заједништву. Декларација је претходила Предлогу, који је прочитан на једном скупу (трибини) у Удружењу књижевника Србије, није нигде објављен, није био доступан и ником није упућен. Ипак, документи су изједначени и „кривица” је равномерно распоређена, слободније речено „братски”. И даље се о Предлогу мало зна. Не зна се поуздано ко је иницијатор предлога, не зна се поуздано ни ко је аутор текста. Књига Слободана Селинића са бројним оригиналним документима је драгоцен прилог овој теми: „Иницијатори 'Предлога' су били српски интелектуалци, углавном окупљени око 'Просвете', међу којима су водећу улогу играли Борислав Ми-

нас је јасно да је Декларација била удар „у саме темеље заједничке државе” и да је иницијатор ове идеје имао „државни врх са собом” (Брборић 2000: 13).

${ }^{6}$ На Брионском пленуму (1966) смењен је Александар Ранковић, чиме су створени услови и за уставне промене, слабљење савезне државе и јачање власти на републичком нивоу. Тако су све наше републике, уз ваљану припрему, после тридесетак година постале самосталне државе.

${ }^{7}$ У литератури се најчешће говори о 18 институција, али се пажљивим бројањем лако може закључити да је посреди 19 институција. Чак и у књизи Deklaracija o nazivu i položaju hrvatskog književnog jezika 1967-2017. vijesti, komentari, osude, zaključci; U povodu 50. obljetnice donošenja налазимо тај превид. Заправо, Декларащија је настала у Матици хрватској, а после ју је потписало још 18 институција. Овај број постао је број са којим се „манипулисало” јер је заборављена Матица хрватска, као деветнаеста. 
хајловић Михиз, Антоније Исаковић, Зоран Гавриловић, Матија Бећковић, Душан Радовић и Брана Црнчевић” (Селинић 2017: 11). ${ }^{8}$

\section{4. ШТА СУ ТРАЖИЛИ ДЕКЛАРАЦИЈА И ПРЕДЛОГ?}

Колика је реална и симболичка важност Декларащије, најбоље сведоче хвалоспеви, које и сада доживљава у Републици Хрватској, док Предлог у Србији нико не помиње, не знамо ни шта је у њему стајало, ни ко су његови потписници. Заправо, до текста Предлога у Србији дуго се није могло доћи, и то представља својеврсни феномен. Бранислав Брборић пише да је седамдесетих година прошлог века (од 1971. године) тражио текст Предлога, а да га је нашао тек 1980. године, и то у загребачкој Борби, у магацину Народне библиотеке Србије (Брборић 2000: 17).

Овде се морамо сетити речи Јована Дучића из књиге Верујем у Бога и у сриство, које је написао почетком Другог светског рата: „Хрвати нису никад марили за славизам, нити без неповерења говорили о југославизму. Они су славизам идентификовали са руским православљем, а југославизам са балканством. Зато су обоје сматрали неподударним са хрватском идејом о култури, западњачкој, значи већим делом католичкој. (...) У овом су се Хрвати битно разликовали од српског схватања југославизма. Никад Хрвати нису замишљали могућност да свој хрватски видик замраче југословенском магловитошћу, ни да размене свој стари хрватски грош за какву неизвесну југословенску пару" (Дучић 2015: 11).

Колико је Деклараиија била важан догађај, и колико је слављена у језичком и политичком животу Хрватске, најбоље сведочи књига Deklaracija o nazivu i položaju hrvatskog književnog jezika 1967.-2017. vijesti, komentari, osude, zaključci; U povodu 50.obljetnice donošenja. ${ }^{9}$ Наиме, на пола века од Декларације „Matica hrvatska željela je novom knjigom podsjetiti na okolnosti u kojima je nastala Deklaracija i na reakcije koje su usledile pa je zamolila profesora Marka Samardžiju, istaknutoga hrvatskog jezikoslovca, da napravi izbor iz važnih

${ }^{8}$ Ипак, књига Слободана Селинића не осветљава питања језичких (не)споразума између Срба и Хрвата и то аутор јасно каже: „Наш циљ није да улазимо у лингвистичка тумачења појма српскохрватски језик или односа српског и хрватског језика и одговарамо на питања ко је био у праву и да ли је то један језик или су два. Циљ рада је да осветли језички спор из 1967. као једно од питања које је у годинама уставних, политичких и друштвених промена у Југославији и све већег слабљења савезне државе, пред налетом републичких (националних) центара, додатно доприносило заоштравању међунационалних односа" (Селинић 2017: 11).

${ }^{9}$ Књига има 332 нумерисане стране, објављена је у библиотеци Посебна издања Матице хрватске, уз „потпору” Министарства културе Републике Хрватске и Града Загреба, приредио је и поговор написао Марко Самарџија, предговор је написао академик Стјепан Дамјановић, председник Матице хрватске. 
dokumenata i karakterističnih reakcija te da ponudi svoje viđenje deklaracije i svega što se oko nje događalo" (Декларација 2017: 10).

Марко Самарџија каже да је Устав ФНРЈ из 1946. године дозвољавао засебан хрватски језик и цитира чл. 65. Устава „Zakoni i drugi opšti propisi Federativne Narodne Republike Jugoslavije objavljuju se na jezicima narodnih republika" (Декларација 2017: 229). Ово се може двојако тумачити. Прво, да су постојала три језика, тј. српскохрватски (хрватскосрпски), словеначки и македонски и, друго, да свака „народна република” има засебан језик. Ова друга тврдња није и не може бити тачна, јер да је у њој било имало истине, не би било Новосадског књижевног договора. ${ }^{10}$ После Другог светског рата и Новосадског књижевног договора нико није говорио о постојању засебних језика, нити засебним називима за језик у Босни и Херцеговини и Црној Гори. Очито, овде је реч о лошим намерама или о „накнадној памети”. Научне чињенице и доступна литература сведоче другачије. Чињеница је да је Матица српска 1953. године у свом Летопису покренула Анкету о питањима српскохрватског језика и правописа и да је хрватска страна била равноправна у припреми и одржавању скупа у Новом Саду. Неспорна је чињеница да је Правопис рађен компромисно (од 1956. до 1960) и да је настојао да „Помири” разлике у фонолошким традицијама Александра Белића, с једне стране, и Ивана Броза и Драгутина Боранића, с друге стране. Не може се оспорити чињеница да је правописна комисија била заједничка (Радомир Алексић, Александар Белић, Јован Вуковић, Људевит Јонке, Радован Лалић, Славко Павешић, Павле Рогић, Михаило Стевановић, Јосип Хам, Милош Хаџић и Мате Храсте), коначну стилизацију текста су дали Михаило Стевановић и Људевит Јонке, а речник су „средили” Радомир Алексић, Јован Вуковић и Мате Храсте. Правопис је имао и екавско и ијекавско издање (ћирилица и латиница) и нема ни слова о ,језицима народних република”. Увелико се одвијао и рад на Речнику, а два тома су урађена и објављена заједнички. Хрвати су после тај пројекат напустили и за то кривили Србе, али је Сњежана Кордић изнела један аргумент који најбоље сведочи о чему се ради. Вреди то цитирати: „Budući da su u izradi Rječnika sudjelovale i hrvatska i srpska redakcija, hrvatski kritičari Rječnika koristili su još jednu metodu: prebacivali su beogradskoj redakciji zbog nekih pojedinosti u Rječniku, prešućujući da je baš te dijelove Rječnika izradila zagrebačka redakcija. Npr. prebacivali su što od četiri primjera za riječ iskopnjeti nijedan nije od hrvatskih pisaca, prešućujući da je slovo I izrađivala zagrebačka redakcija. Usto su na osnovi tog primjera izveli zaključak da je dokumentacija iz srpskih pisaca općenito više zastupljena u Rječniku" (Кордић 2010: 312). Оваквих аргумената код Сњежане Кордић има још и они заправо најбоље сведоче о

${ }^{10}$ М. Самарџија се позива и на одлуке АВНОЈ-а, из 1944. године, где стоји да ће одлуке и документа бити објављивана на „српском, хрватском, словеначком и македонском језику” (Декларација 2017: 298). 
бројним поступцима хрватских језичких стручњака после Другог светског рата, посебно после Новосадског књижевног договора. ${ }^{11}$

Декларација је била упућена Савезној и Републичкој скупштини, и то као предлог за промену Устава (Селинић 2017: 140). Председништво Савезне скупштине (председник Едвард Кардељ) је 1. априла 1967. одговорило Матици хрватској с образложењем да је то „атак на братство и јединство народа Југославије и да је нашло да нема места да се у телима скупштине изнесу на разматрање предлози изнети у Декларацији" (Селинић 2017: 141).

У Србији данас нема превише радова о Предлогу за размишьљање и остаје нејасно шта се заправо десило. Изузетак је књига историчара Слободана Селинића Србија и језички сукоби у Југославији 1967. године, али је овде мало речи о лингвистичким чињеницама, мада књига доноси доста докумената и, са историјске тачке гледишта, лепо осветљава овај период. ${ }^{12}$

Ми ни данас са сигурношћу не можемо тврдити колико је писаца потписало Предлог. Обично се каже да је у питању четрдесетак српских писаца, чланова Удружења књижевника Србије, већина њих су били млади писци, али је било и већ афирмисаних стваралаца. Није мали број оних који су потписе повукли, образложења су била различита, али се тешко може замислити каквим су притисцима били изложени. Бранислав Брборић каже да у том тексту нема ничег ни националистичког, ни шовинистичког, већ да је посреди недовршен текст као одговор на Декларацију и јасну поруку из Загреба, али су етикете и оптужбе које је Предлог добио биле најтеже могуће оптужбе политичких и партијских вођа. „Разуме се, он је био 'брзоплет' и 'недомишљен' (да није био такав, нашла би се управа барем једне културно-научне установе или организације, или већег броја њих, да га лукавије срочи, да се исто каже, али у виду упозорења или консеквенце)" (Брборић 2000: 17).

По истраживању Слободана Селинића, партијски (државни) органи су врло брзо реаговали и констатовали да су Декларащија и Предлог изазвали револт међу „радним људима и грађанима” и одмах су партијске организације заузеле „идејно-политички став”, а о језику је лично говорио и Јосип Броз Тито. Партијски комитет Београда први је реаговао, одмах су се „оградили од текста” неки потписници (Душан Анђелковић, Раде Пешић, Живорад Михајловић

${ }^{11}$ И Сњежана Кордић јасно сведочи о хрватском прихватању Вуковог и вуковског језика код Хрвата и 2010. године у књизи Језик и начионализам, поред осталог, каже: „Naime, filolozi u Zagrebu su u 19. st. samoinicijativno odlučili po uzoru na Vuka Karadžića uzeti ijekavski štokavski za nadregionalni jezik. Čak i Stjepan Babić priznaje da 'ideja jezičkog zajedništva potekla od iliraca' (...) 'ne biti vukovcem u to doba, značilo bi opirati se znanosti', do danas je Karadžić počasni građanin grada Zagreba" (Кордић 2010: 284).

${ }^{12}$ Слободан Селинић је виши научни сарадник Института за новију историју Србије, књига је објављена 2017. године у малом тиражу, нема је у нашим књижарама, а ретка је и у библиотекама. 
Шиља и Раде Николић). Други су у медијима јавно повлачили потпис (Божидар Шујица). Партијске организације су брзо реаговале и у документима које је Селинић учинио доступним стоји да су Предлог потписала 42 књижевника, чланови Удружења књижевника Србије (Селинић 2015: 167). ${ }^{13}$

Тешко је замислити како се власт понашала према потписницима Предлога, мало је оних који се нису „кајали”, а изгледа да о Предлогу нису рекли ниједну лошу реч једино Зоран Гавриловић и Борислав Михајловић Михиз. Михиз је јавно рекао да тај текст није био намењен јавности и да је учествовао у његовом састављању. То је била велика храброст! Међу потписницима Предлога је био и Момо Капор, и он је један од ретких који није повукао потпис. ${ }^{14}$ Сви чланови партије су добили партијске казне - „опомена, последња опомена, укор...”.

Нама се чини да се у Србији о Предлогу мало писало, јер је то одговарало и неким од потписника, због њиховог повлачења потписа и неким коментарима, очито датим под различитим притисцима. Истина, ово је само претпоставка.

Као додатак, у прилогу доносимо и оба документа, Декларацију о називу и положају хрватског књижевног језика и Предлог за размишьљање.

${ }^{13}$ Неки потписници су, засигурно под притиском, налазили невероватне изговоре и повлачили потписе: да су докуменат потписали „у пијаном стању”, „мислим да је Предлог штетан и веома аполитичан акт”, „предлог је политички штетан и шовинистички”, „уперен против основних тековина наших народа”, ,једна очигледна бесмислица”, „стид ме је што сам уплетен у шпекулантске послове”, „Предлог је штетан акт - супротан мом политичком убеђењу”, „грех је већи него казна коју ћу добити”, „То је умноболан текст”, „Предлог је излив мржње”, „ставио сам потпис испод погрешног текста”, „Признам да сам погрешио и потписао текст који је објективно штетан” (Селинић 2015: 166-167). У једној белешци коју доноси Селинић данас симпатично звучи констатација да су Матија Бећковић и Брана Црнчевић говорили „патетично и безобразно", да они нису чланови партије и да не знају коме да одговарају, коме су политички одговорни и ко је њима компентетан да суди (Селинић 2015: 172). Потписници Предлога за размишљање су: Зоран Гавриловић, Бранко В. Радичевић, Никша Стипчевић, Антоније Исаковић, Иван В. Лалић, Зоран Мишић, Александар Петровић, Борислав Михајловић Михиз, Света Лукић, Брана Црнчевић, Богдан Чиплић, Љубомир Симовић, Матија Бећковић, Радивоје Пешић, Светлана Велмар-Јанковић, Слободан Стојановић, Бранимир Шћепановић, Жика Лазић, Радослав Златановић, Петар Џаџић, Никола Трајковић, Божидар Шујица, Миодраг Шијаковић, Мира Алечковић, Стеван Раичковић, Светислав Мандић, Гојко Јањушевић, Саша Трајковић, Душан Анђелковић, Милорад Павић, Зуко Џумхур, Јован Христић, Раде Николић, Момо Капор, Живорад Михајловић Шиља, Момчило Миланков, Душан Радовић, Васа Павковић, Миодраг Јуришевић, Борислав Пекић, Александар Петров и Живорад Стојковић. Према доступним подацима, Предлог је потписао 21 члан партије, половина од укупног броја потписника. Ипак, укупан број потписника није поуздано утврђен (Селинић 2017: 144).

${ }^{14}$ У књизи Рајка Петрова Ноге Запиши то, Рајко налазимо констатацију да је Капор био „искушан на Предлогу за размишљағе” (Ного 2011: 152), али и на још неколико афера. 


\section{ПРИЛОГ 1}

Deklaracija o nazivu i položaju hrvatskog književnog jezika ${ }^{15}$

Višestoljetna borba jugoslavenskih naroda za nacionalnu slobodu i socijalnu pravdu kulminirala je revolucionarnim preobražajem u razdoblju od 1941-1945. Tekovine Narodnooslobodilačke borbe i socijalističke revolucije omogućile su svim narodima i narodnostima u Jugoslaviji da uđu u novu fazu njihova povijesnog postojanja. Oslanjajući se na temeljna načela socijalizma o pravu svakog čovjeka da živi slobodan od svake podjarmljenosti i o pravu svakog naroda na potpun suverenitet i neograničenu ravnopravnost sa svim drugim nacionalnim zajednicama, Slovenci, Hrvati, Srbi, Crnogorci i Makedonci formirali su federativni savez, sazdan od šest socijalističkih republika, kao jamstvo te uzajamne ravnopravnosti, međusobnog bratstva i socijalističke suradnje.

Načelo nacionalnog suvereniteta i potpune ravnopravnosti obuhvaća i pravo svakoga od naših naroda da čuva sve atribute svoga nacionalnog postojanja i da maksimalno razvija ne samo svoju privrednu, nego i kulturnu djelatnost. Među tim atributima odsudno važnu ulogu ima vlastito nacionalno ime jezika kojim se hrvatski narod služi, jer je neotuđivo pravo svakoga naroda da svoj jezik naziva vlastitim imenom, bez obzira radi li se o filološkom fenomenu koji u obliku zasebne jezične varijante ili čak u cijelosti pripada i nekom drugom narodu.

Novosadski dogovor opravdano je deklarirao zajedničku lingvističku osnovu srpskog i hrvatskog književnog jezika ne poričući historijsku, kulturno-historijsku, nacionalnu i političku istinu o pravu svakoga naroda na vlastiti jezični medij nacionalnog i kulturnog života. Te su tekovine formulirali i ustavni tekstovi, i Program Saveza komunista, političkog predvodnika naših naroda u revolucionarnoj borbi.

Ali usprkos jasnoći osnovnih načela, stanovite nepreciznosti u formulacijama omogućavale su da ta načela budu u praksi zaobilažena, iskrivljavana i kršena unutar širih pojava skretanja u realnosti našega društvenog i ekonomskog života. Poznato je u kojim su okolnostima u našoj zemlji oživjele tendencije etatizma, unitarizma, hegemonizma. U vezi s njima pojavila se i koncepcija o potrebi jedinstvenog »državnog jezika«, pri čemu je ta uloga u praksi bila namijenjena srpskom književnom jeziku zbog dominantnog utjecaja administrativnog središta naše državne zajednice. Usprkos VIII kongresu, IV i V plenumu CK SKJ, koji su u našim danima posebno naglasili važnost socijalističkih načela o ravnopravnosti naših naroda pa, prema tome, i njihovih jezika, putem upravnog aparata i sredstava javne i masovne komunikacije (saveznih glasila, Tanjuga, JRTV u zajedničkim emisijama, PTT, željeznicama, tzv. materijala ekonomske i političke literature, filmskih žurnala, raznih administrativnih obrazaca), zatim putem jezične prakse u JNA, saveznoj upravi, zakonodavstvu, diplomaciji i političkim organizacijama, faktično se i danas

${ }^{15}$ Текст Декларације донет је према књизи књиге Матице хрватске (Декларација 2017: 19-23). 
provodi nametanje »državnog jezika«, tako da se hrvatski književni jezik potiskuje i dovodi u neravnopravan položaj lokalnog narječja.

Osobito važne inicijative privredne i društvene reforme, oslanjajući se na bitna svojstva našeg samoupravnog socijalističkog društva, obvezuju nas da na području svoga djelovanja - jezika, književnosti, znanosti i kulture uopće - poduzmemo sve potrebno da se u neposrednoj praksi ostvaruje i ostvare sva izložena načela našeg socijalističkog sustava.

Na toj osnovi potpisane hrvatske kulturne i znanstvene ustanove i organizacije smatraju da je neophodno potrebno:

1) Ustavnim propisom utvrditi jasnu i nedvojbenu jednakost i ravnopravnost četiriju književnih jezika: slovenskoga, hrvatskoga, srpskoga, makedonskoga.

U tu svrhu treba izmijeniti formulaciju iz Ustava SFRJ, čl. 131, koja bi morala glasiti ovako:

„Savezni zakoni i drugi opći akti saveznih organa objavljuju se u autentičnom tekstu na četiri književna jezika naroda Jugoslavije: srpskom, hrvatskom, slovenskom, makedonskom. U službenom saobraćaju organi federacije obvezno se drže načela ravnopravnosti svih jezika naroda Jugoslavije."

Adekvatnom formulacijom treba osigurati i prava jezika narodnosti u Jugoslaviji.

Dosadašnja ustavna odredba o »srpskohrvatskom odnosno hrvatskosrpskom jeziku« svojom nepreciznošću omogućuje da se u praksi ta dva usporedna naziva shvate kao sinonimi, a ne kao temelj za ravnopravnost i hrvatskog i srpskog književnog jezika, jednako među sobom, kao i u odnosu prema jezicima ostalih jugoslavenskih naroda. Takva nejasnoća omogućuje da se u primjeni srpski književni jezik silom stvarnosti nameće kao jedinstven jezik za Srbe i Hrvate. Da je stvarnost zaista takva, dokazuju mnogobrojni primjeri, a među njima kao najnoviji nedavni Zaključci pete skupštine Saveza kompozitora Jugoslavije. Ti su zaključci objavljeni usporedno u srpskoj, slovenskoj i makedonskoj verziji kao da hrvatskoga književnoga jezika uopće nema ili kao da je istovjetan sa srpskim književnim jezikom.

Potpisane ustanove i organizacije smatraju da u takvim slučajevima hrvatski narod nije zastupan i da je doveden u neravnopravan položaj. Takva se praksa ni u kojem slučaju ne može opravdati inače neosporenom znanstvenom činjenicom da hrvatski i srpski književni jezik imaju zajedničku lingvističku osnovu.

2) U skladu s gornjim zahtjevima i objašnjenjima potrebno je osigurati dosljednu primjenu hrvatskoga književnog jezika u školama, novinstvu, javnom i političkom životu, na radiju i televiziji kad se god radi o hrvatskom stanovništvu, te da službenici, nastavnici i javni radnici, bez obzira otkuda potjecali, službeno upotrebljavaju književni jezik sredine u kojoj djeluju. 
Ovu Deklaraciju podnosimo Saboru SRH, Saveznoj skupštini SFRJ i cjelokupnoj našoj javnosti da se prilikom pripreme promjene Ustava izložena načela nedvosmisleno formuliraju i da se u skladu s time osigura njihova potpuna primjena u našem društvenom životu.

Иза текста стале су следеће институције Републике Хрватске:

Matica hrvatska, Društvo književnika Hrvatske, PEN-klub, Hrvatski centar, Hrvatsko filološko društvo, Odjel za filologiju Jugoslavenske akademije znanosti i umjetnosti, Odjel za suvremenu književnost Jugoslavenske akademije znanosti i umjetnosti, Institut za jezik Jugoslavenske akademije znanosti i umjetnosti, Institut za književnost i teatrologiju Jugoslavenske akademije znanosti i umjetnosti, Katedra za suvremeni hrvatskosrpski jezik Filozofskoga fakulteta u Zadru, Katedra za suvremeni hrvatskosrpski jezik Filozofskoga fakulteta u Zagrebu, Katedra za povijest hrvatskog jezika i dijalektologiju Filozofskoga fakulteta u Zagrebu, Katedra za stariju hrvatsku književnost Filozofskoga fakulteta u Zadru, Katedra za stariju hrvatsku književnost Filozofskoga fakulteta u Zagrebu, Katedra za noviju hrvatsku književnost Filozofskoga fakulteta u Zadru, Katedra za noviju hrvatsku književnost Filozofskoga fakulteta u Zagrebu, Institut za lingvistiku Filozofskoga fakulteta u Zagrebu, Institut za nauku o književnosti Filozofskoga fakulteta u Zagrebu, Staroslavenski institut u Zagrebu, Društvo književnih prevodilaca Hrvatske. ${ }^{16}$

\section{ПРИЛОГ 2}

\section{Предлог за размишљање групе писаца ${ }^{17}$}

Група писаца разматрала је „Декларацију о називу и положају хрватског књижевног језика", коју је прогласило Друштво књижевника Хрватске, а коју су претходно усвојиле најзначајније научне и културне институције Хрватске. После свестраног разматрања овог значајног историјског документа група писаца сматра легитимним и неотуђивим правом сваког народа да доноси одлуке о називу и развоју сопственог језика.

Група писаца Србије сматра да су институције које су регулисале „Декларацију о називу и положају хрватског књижевног језика” најмеродавније

${ }^{16}$ Већ смо рекли да се у литератури често говори да је текст Декларације потписало 18 институција („хрватске културне и знанствене установе и организације”). Овде се налази списак свих 19 институција, које се потписале Декларацију (Прилог 1). Слободан Селинић каже да је испод текста Деклараиије било 19 институција и да су уместо Катедре за југославенске књижевности Филозофског факултета у Задру посебно наведене две - Катедре за старију и Катедра за новију хрватску књижевност (Селинић 2017: 105). Ипак, чешће се помиње број од 19 институција.

${ }^{17}$ Текст Предлога преузет је из књиге Бранислава Брборића О језичком расколу - социолингвистички огледи I (Брборић 2000: 16-17). 
за питање хрватског књижевног језика и њихову декларацију сматра репрезентативном и мериторном.

Стога група писаца која предлаже ову резолуцију, не улазећи у историјске и научне видове проблема, и имајући у виду чињеницу која произилази из захтева ове декларације, сматра Бечки и Новосадски договор поништеним. Хрватски и српски језик развијаће се у пуној самосталности и равноправности. Група писаца која предлаже резолуцију сматра природним да се ово има односити и на све језике народа Југославије и на све националне азбуке: латиницу, македонску и српску ћирилицу, и правописе.

Група писаца која предлаже резолуцију подноси захтев Скупштини Србије, Удружењу књижевника Србије, па према томе и захтев Савезној скупштини, Скупштини Социјалистичке Републике Србије и Сабору Социјалистичке Републике Хрватске да се убудуће доследно и обавезно избаце из званичне употребе називи хрватско-српски и српско-хрватски језици и да се у администрацији федерације, савезним прописима, у дипломатији, законодавству, политичким организацијама, железницама, ПТТ, Танјугу, Лексикографском заводу Југославије, царини, ЈНА, свуда спроводи равноправност свих југо-словенских језика и азбука.

Поводом тога група писаца која предлаже ову резолуцију захтева да Радио-телевизија Београд да престане да неовлашћено игра улогу централног југословенског студија, и да у свом локалном програму уведе ћирилицу, а да се у заједничким емисијама Радио-телевизије Југославије паралелно употребљавају оба писма.

Удружење, односно група која предлаже, сматра да није сувишан ниједан напор и да није велика ниједна цена да равноправност језика и писама наших народа буде увек и доследно поштована.

Група писаца која предлаже резолуцију сматра за своју дужност и право да скрене пажњу на један проблем који у светлости горњих захтева постаје још актуелнији:

Уставом је гарантовано право на самосталан развој националног језика и културе свих наших народа и народности. Афирмација самосталности назива и развоја хрватског и српског језика захтевају да ово право буде уставним прописима обезбеђено и свим Хрватима који живе на територији СР Србије и свим Србима који живе на територији СР Хрватске.

Група писаца захтева да се у уставе СР Србије и СР Хрватске унесу прописи који обезбеђују свим Хрватима и Србима право на школовање на свом језику и писму и по својим националним програмима. Право на употребу свог националног језика и писма у општењу са свим органима власти, право на стварање својих културних друштава, завичајних музеја, издавачких и 
новинских предузећа, једном речју право на неометано и слободно неговање свих видова своје националне културе. ${ }^{18}$

\section{5. ЗАКЉУЧАК}

Језичко јединство бивших „истојезичних република” постигнуто је знатно пре стварања прве Југославије, и то заправо преузимањем Вуковог и вуковског модела српског језика и правописа језика.

После Првог светског рата то јединство је и званично потврђено, уз повремена оспоравања само са хрватске стране. То је посебно било изражено пред Други светски рат и, екстремно, током рата.

После Другог светског рата уследио је Новосадски књижевни договор, с јасним циљем да језичко јединство ојача, да се уради заједнички правопис, заједнички речник и заједничка терминологија. Све то, уз неспорни пристанак језичких стручњака, књижевника и културних радника и институција из Хрватске, и било каквог оспоравања из Црне Горе и Босне и Херцеговине.

После Брионског пленума, као припрема за „Хрватско прољеће” и најављене уставне промене, уследила је добро смишљена и дуго припремана (ре)акција из Хрватске и Декларащија је као званични документ свих релевантних хрватских институција упућена и републичким и савезним институцијама. Из Београда је стигла брза реакција групе писаца названа Предлог за размишљање. Та два документа одмах су стављена у исту раван.

Декларација је у Хрватској хваљен и слављен докуменат, док ми у Србији и даље нисмо довољно истражили све околности појављивања Предлога и реакција на тај текст. Намера овог прилога је да скрене пажњу на овај период и на овај докуменат, у нади да ће сви документи око Предлога и реакције институција и појединаца бити јавно доступни, уз ваљане коментаре. Књига Слободана Селинића је само почетак тога посла.

${ }^{18}$ Текст Предлога је прочитао Зоран Гавриловић, докуменат није био умножен и тешко је рећи ко га је све имао у рукама, као што није поуздано ни ко га је све потписао (мислимо на коначан број потписника). Гавриловић је прочитао и имена потписника, али је очигледно да се до документа у изворном облику није могло доћи, стенограм је сигурно постојао и на основу њега дошло се до доступног текста Предлога. Гавриловић је, по неким стенографским белешкама, говорио како нека имена не може да прочита, реч је о нечитким потписима, „текст је прочитао и вратио у џеп”. Оригиналан текст Предлога није сачуван. 


\section{ЛИТЕРАТУРА}

Брборић 2000: Бранислав Брборић, О језичком расколу - соцчиолингвистички огледи I, Београд - Нови Сад: ЦПЛ - Прометеј.

Брборић 2015: Вељко Брборић, Правопис и икола, Београд: Друштво за српски језик и књижевност Србије.

Броз1892: Ivan Broz, Hrvatski pravopis, Zagreb: Tisak Ign. Granitza u Zagrebu.

Брозовић 1985: Dalibor Brozović, Jezička i pravopisna previranja u Hrvatskoj na prijelazu 19. u 20. stoljeće, Jezik, XXIII, br. 1. str. 1-15.

Декларација 2017: Deklaracija o nazivu i položaju hrvatskog književnog jezika 1967.-2017. vijesti, komentari, osude, zaključci; U povodu 50. obljetnice donošenja, Zagreb: Matica hrvatska (priredio i pogovor napisao Marko Samardžija).

Дучић 2015: Јован Дучић, Верујем у Бога и у српство, Београд: Алгоритам.

Ивић 1971: Павле Ивић, Српски народ и његов језик, Београд: Српска књижевна задруга.

Ивић 1998: Павле Ивић, Из прошлости српског правописа, y: K новој nuсмености, Београд: Научна књига, 11-15.

Ковачевић 2005: Милош Ковачевић, Против неистина о српском језику, Пале: Српско просвјетно и културно друштво „Просвјета”.

Кордић 2010: Snježana Kordić, Jezik i nacionalizam, Zagreb: Darieux.

Милановић 2004: Александар Милановић, Кратка историја српског књижевног језика, Београд: Завод за уџбенике и наставна средства.

Нејлор 1996: Kenet Nejlor, Sociolingvistički problemi među Južnim Slovenima, Beograd: Prosveta.

Ного 2011: Рајко Петров Ного, Запиши то, Рајко, Београд: Српска књижевна задруга.

Окука 2006: Miloš Okuka, Srpski na kriznom putu, Istočno Sarajevo: Zavod za udžbenike i nastavna sredstva.

Правопис 1960: Правопис српскохрватскога књижевног језика са правописним речником (израдила правописна комисија), Нови Сад - Загреб: Матица српска - Матица хрватска.

Селинић 2017: Слободан Селинић, Србија и језички сукоб у Југославији 1967, Београд: Институт за новију историју Србије. 
Танасић 2012: Срето Танасић, Језичка политика у Босни и Херцеговини послије Другог свјетског рата, у: Језик и писмо у Републици Српској, Бања Лука: Академија наука и умјетности Републике Српске.

Шипка 2006: Милан Шипка, Језик и политика (социолингвистичке анализе), Београд: Београдска књига.

\title{
LINGUISTIC DISPUTES STEMMING FROM THE NOVI SAD LITERARY AGREEMENT: FROM A DECLARATION TO A PROPOSAL
}

\begin{abstract}
Summary
The paper deals with the linguistic rift between the Serbs and Croats after the literary agreement reached in Novi Sad. The aim of the Novi Sad Agreement was to strengthen the linguistic unity of the Serbo-Croatian language. It initiated the compilation of a joint orthographic manual, a joint dictionary and joint terminology. Still, in 1967, the most important cultural institutions of the then Republic of Croatia, led by Matica hrvatska and the Croatian Writers' Association supported the Declaration on the Name and Status of the Croatian Literary Language. Belgrade responded with an unofficial document titled the Proposal for Reflection. This was a prelude to the Croats' withdrawal from the Novi Sad Agreement, the joint language and the joint state. This paper brings both documents and attempts to elucidate this period and highlight some indisputable facts about how linguistic discord gave rise to social discord, which resulted in the collapse of the second Yugoslavia, emergence of new states and renaming of the joint language into national languages.

Keywords: Serbian language, linguistic disagreements and conflicts, Novi Sad Literary Agreement, Declaration on the Language, Proposal for Reflection.
\end{abstract}

Veljko B. Brborić 